\title{
Ring Interferometric Magnetic Field Optical Sensor Using a Garnet Single Crystal
}

\author{
H. Tamura, H. Tozuka, T. Nakaya, and O. Kamada \\ Polytechnic University, 4-1-1 Hashimotodai, Midori-ku, Sagamihara, Kanagawa 252-5196, Japan
}

\begin{abstract}
A magnetic-field sensor based on reflection-ring interferometry is proposed to achieve a probing scheme with a polarization maintaining fiber (PMF). We used $\mathrm{Tb}_{0.19} \mathrm{Y}_{0.81} \mathrm{Fe}_{5} \mathrm{O}_{12}$ ((TbY)IG) crystals with a striped magnetic domain structure as a Faraday element to enable both parallel and perpendicular fields to the propagating direction of the optical wave to be measured. A linear magnetization curve without hysteresis and a linear Faraday effect were expected to be obtained as the magnetization process of rotation occurred in each striped magnetic domain. This assumption was confirmed in an experiment. Experimental results such as sensitivity and $S N R$ were well explained by this model. The obtained sensor sensitivity was $1.08 \times 10^{-3} \% /(\mathrm{A} / \mathrm{m})$, and good linearity of sensor output was obtained over a wide dynamic range between $1 \mathrm{~A} / \mathrm{m}$ to $10^{4} \mathrm{~A} / \mathrm{m}$.
\end{abstract}

Key words: ring interferometry, magnetic-field optical sensor, Faraday effect, rare-earth iron garnet, magnetization rotation process.

\section{ガーネット単結晶を用いたリング干渉型光磁界センサ}

田村仁志・戸塚俊秀・中谷努・鎌田修

職業能力開発総合大学校, 神奈川県相模原市緑区橋本台 4-1-1（干252-5196）

\section{1. はじめに}

ファラデー効果を利用した光磁界センサは，高絶縁性， 耐電磁ノイズ性，非接触でリモートセンシングが可能であ るので，特に大電流を測定するためにファイバコイルを用 いたものが, 電力設備や工場設備で実用化がなされている1) 一方，希土類鉄ガーネット結晶のファラデー効果を用いる と高感度が実現され ${ }^{2}$, さらに磁化の回転に伴うファラデー 効果は高速応答が可能であることから，高周波電流測定に 応用されている3).このような光磁界センサの用途を考える と，光ファイバ先端にファラデー素子を設けたプローブ型 センサが有用であるが，振動などの外乱に対して安定に動 作をすることが要求される.

リング干渉型磁界センサは共通光路干渉法の一種であり, 振動などによる光路長の変動の影響が相殺される特徽を持 つ4).また，プローブ型センサヘッド部の実現のためには， 光伝送路として偏光状態が変化しない定偏波ファイバ

(Polarization Maintaining Fiber: PMF) を用いれば良い が，逆に大きな複屈折とその温度変化が実用上の問題点で ある。しかし，リング干渉計に挿入して用いれば，それら の影響は補償され, 安定な光磁界センサの構成が得られこ とから，今回以下のような検討を行ったので報告する.

センサヘッド部には，縞状磁区構造を有する希土類鉄ガ 一ネット結晶(TbY)IGを用いる。Flux法で育成された (TbY)IG単結晶は，(110)面下の成長域で，成長誘導磁気異 方性により縞状磁区構造を持ち，ヒステリシスの無い直線 的な磁化過程とファラデー効果が得られるので，磁界セン サ用素子として有用である5)。今回は，プローブに対して平 行な磁界を測定する素子に加えて，新たに垂直な磁界の測 定が可能な素子の提案とその評価を行う。そして, リング
干渉型センサを構成して，センサ特性の評価を行うが，従 来の光源であるレーザダイオード(Laser Diode：LD)に換 えて，受光器に発生する雑音を改善するために，可干渉長 の短いスーパールミネッセントダイオード (Super Luminescent Diode: SLD)6）を用いた場合の実験結果を報 告する. そして，ガーネット結晶を用いたリング干渉型光 磁界センサが，高感度で安定なプローブ型センサの実現に 有用であることを示す.

\section{2. 実験方法}

\section{1 リング干渉型光磁界センサの構成}

今回提案するリング干渉計を用いた反射型光磁界センサ の構成をFig. 1 に示す. 光源からの光波は，偏光子および 無偏光ビームスプリッタを透過後，右迴りの光波 $\left(\mathbf{e}_{\mathrm{cw}}\right)$ と左 迴りの光波 $\left(\mathbf{e}_{\mathrm{ccw}}\right)$ に分かれて伝搬し，偏光ビームスプリッタ により反射型のセンサヘッド部に導入される。光伝送路と して定偏波ファイバを用いるが，直線偏光状態が保存され るように，主軸方向と偏光方向が一致して伝搬するように

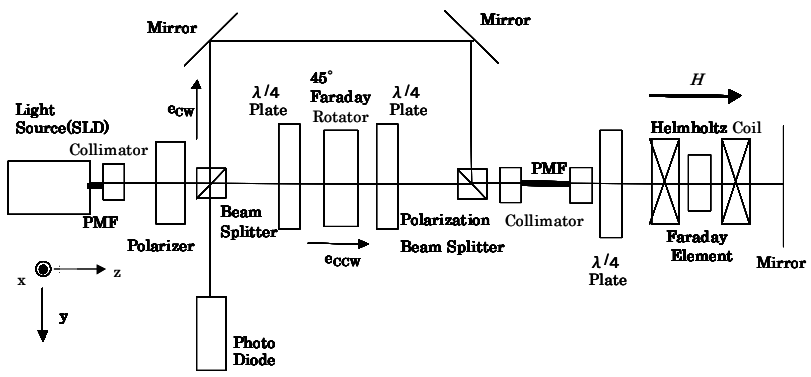

Fig. 1 Schematic diagram of experimental setup. 
結合される。ヘッド部は，方位 $45^{\circ}$ の $\lambda / 4$ 板と垂直反射用 ミラーの間にファラデー素子を挿入した構成であり，左右 の円偏光がファラデー効果による位相を受ける。ヘッド部 からの反射光は直線偏光に戻されており, それぞれ入射時 と直交した定偏波ファイバの主軸方向を伝搬後，偏光ビー ムスプリッタにより入射時と反対方向の光路を伝播し，フ オトダイオードに入射される。 また, 直線性が良好なセン サ出力を得るために, $\lambda / 4$ 板・ $45^{\circ}$ ファラデー回転子・ $\lambda / 4$ 板を組み合わせた素子を光路に挿入して, 光学的なバイア スを与えている. このような構成のセンサ出力は, 次式の ジョーンズマトリックス法を用いて計算することができる.

$$
\begin{aligned}
\mathbf{e}_{\mathrm{cw}}= & \overleftarrow{\mathbf{M}}_{\mathrm{BSR}, 0} \overleftarrow{\mathbf{M}}_{\mathrm{QW}, 45} \overleftarrow{\mathbf{M}}_{45 \mathrm{~F}} \overleftarrow{\mathbf{M}}_{\mathrm{QW}, 45} \overleftarrow{\mathbf{M}}_{\mathrm{PBST}, 90} \overleftarrow{\mathbf{M}}_{\mathrm{PMF}, 0} \\
& \overleftarrow{\mathbf{M}}_{\mathrm{QW}, 45} \overleftarrow{\mathbf{M}}_{\mathrm{F}} \mathbf{M}_{\mathrm{m}} \overrightarrow{\mathbf{M}}_{\mathrm{F}} \overrightarrow{\mathbf{M}}_{\mathrm{QW}, 45} \overrightarrow{\mathbf{M}}_{\mathrm{PMF}, 0} \\
& \overrightarrow{\mathbf{M}}_{\mathrm{PBSR}, 0} \mathbf{M}_{\mathrm{m}} \mathbf{M}_{\mathrm{m}} \overrightarrow{\mathbf{M}}_{\mathrm{BSR}, 90} \overrightarrow{\mathbf{M}}_{\mathrm{P}, 0} \mathbf{L}_{0} \\
\mathbf{e}_{\mathrm{ccw}}= & \overleftarrow{\mathbf{M}}_{\mathrm{BST}, 0} \mathbf{M}_{\mathrm{m}} \mathbf{M}_{\mathrm{m}} \overleftarrow{\mathbf{M}}_{\mathrm{PBSR}, 0} \overleftarrow{\mathbf{M}}_{\mathrm{PMF}, 0} \overleftarrow{\mathbf{M}}_{\mathrm{QW}, 45} \\
& \overleftarrow{\mathbf{M}}_{\mathrm{F}} \mathbf{M}_{\mathrm{m}} \overrightarrow{\mathbf{M}}_{\mathrm{F}} \overrightarrow{\mathbf{M}}_{\mathrm{QW}, 45} \overrightarrow{\mathbf{M}}_{\mathrm{PMF}, 0} \overrightarrow{\mathbf{M}}_{\mathrm{PBST}, 90} \\
& \overrightarrow{\mathbf{M}}_{\mathrm{QW}, 45} \overrightarrow{\mathbf{M}}_{45 \mathrm{~F}} \overrightarrow{\mathbf{M}}_{\mathrm{QW}, 45} \overrightarrow{\mathbf{M}}_{\mathrm{BST}, 0} \overrightarrow{\mathbf{M}}_{\mathrm{P}, 0} \mathbf{L}_{0}
\end{aligned}
$$

ここで, 光源の座標系はFig. 1 に示すように, 偏光子の主 軸（x軸, $\mathrm{y}$ 軸）と光波の伝播方向（z軸）と一致させた右手 系の座標をとる. しかしながら，ミラーによる反射で右手 系と左手系間の座標変換がなされることを考慮する必要が ある7). したがって, 各光学素子の表記を $\overline{\overline{\mathbf{M}}}_{\mathrm{s}, \theta}$ としたが, $\rightarrow$ は右手系の座標にある場合を示し， ヒは光波がミラーで反 射されることにより，左手系の座標に変換された場合を示 す. そして, 右手系から左手系への座標変換を示す行列を $\mathbf{r}$ とすると, $\overleftarrow{\mathbf{M}}_{\mathrm{s}, \theta}$ は次式で得られる.

$$
\overleftarrow{\mathbf{M}}_{\mathrm{s}, \theta}=\mathbf{r} \overrightarrow{\mathbf{M}}_{\mathrm{s}, \theta} \mathbf{r}^{-1}
$$

また，Sは光学素子の種類を示し， $\theta$ は方位である. BSR およびBSTは無偏光ビームスプリッタで, それぞれ反射さ れる場合と透過する場合, PBSR, PBSTは, 偏光ビームス プリッタで反射される場合と透過する場合, QWは $\lambda / 4$ 板, $\mathrm{PMF}$ は定偏波ファイバ, $45 \mathrm{~F} は 45^{\circ}$ のファラデー回転素 子， $\mathrm{F}$ は磁界検出用ファラデー素子， $\mathrm{m}$ は反射ミラー， $\mathrm{P}$ は 偏光子を示している. 本構成では光源からの直線偏光をセ ンサ系に入射するので, 計算には直線偏光を基底べクトル としたマトリックスを用いる，そして，L L ジョーンズベクトルであり, 今回は $x$ 軸方向の直線偏光で ある．定偏波ファイバにより与えられる位相を示すマトリ ックスは, 今回は方位が $0^{\circ}$ であるので

$$
\overrightarrow{\mathbf{M}}_{\mathrm{PMF}, 0}=\overleftarrow{\mathbf{M}}_{\mathrm{PMF}, 0}=\left[\begin{array}{cc}
\mathrm{e}^{\mathrm{i} \frac{\pi}{\lambda} \Delta n L_{\mathrm{PMF}}} & 0 \\
0 & \mathrm{e}^{-\mathrm{i} \frac{\pi}{\lambda} \Delta n L_{\mathrm{PMF}}}
\end{array}\right],
$$

である.ここで， $\Delta n$ はモード複屈折率，入は伝搬する光波 の波長， L P PMFは定偏波ファイバの長さを示す. 本構成にお いては， $\mathbf{e}_{\mathrm{cw}}$ と $\mathbf{e}_{\mathrm{ccw}}$ は共に，往路と復路においてPMFのx軸 方向と $\mathrm{y}$ 軸方向の両方を伝搬するので, 複屈折の影響が補償 され，その温度変化の影響も受けないことが期待される. ファラデー効果による位相変化は, ファラデー回転角を $\theta_{\mathrm{F}}$ とすると，

$$
\overrightarrow{\mathbf{M}}_{\theta_{\mathrm{F}}}=\left[\begin{array}{cc}
\cos \theta_{\mathrm{F}} & -\sin \theta_{\mathrm{F}} \\
\sin \theta_{\mathrm{F}} & \cos \theta_{\mathrm{F}}
\end{array}\right], \quad \overleftarrow{\mathbf{M}}_{\theta_{\mathrm{F}}}=\left[\begin{array}{cc}
\cos \theta_{\mathrm{F}} & \sin \theta_{\mathrm{F}} \\
-\sin \theta_{\mathrm{F}} & \cos \theta_{\mathrm{F}}
\end{array}\right],
$$

である.そして，(1)式および(2)式から，入射光の振幅を $e_{0}$ とすると, 受光器上での $\mathbf{e}_{\mathrm{cw}}$ と $\mathbf{e}_{\mathrm{ccw}}$ は以下のように得られる.

$$
\mathbf{e}_{\mathrm{cw}}=\frac{1}{2} e_{0}\left[\begin{array}{c}
-i e^{-i\left(2 \theta_{\mathrm{F}}-\frac{\pi}{4}\right)} \\
0
\end{array}\right], \quad \mathbf{e}_{\mathrm{ccw}}=\frac{1}{2} e_{0}\left[i e^{i\left(2 \theta_{\mathrm{F}}-\frac{\pi}{4}\right)}\right] .
$$

したがって，干渉信号 $I$ は以下の式で表される.

$$
I=\left|\mathbf{e}_{\mathrm{cw}}+\mathbf{e}_{\mathrm{ccw}}\right|^{2}=\frac{1}{2}\left|e_{0}\right|^{2}\left(1-\sin 4 \theta_{\mathrm{F}}\right)
$$

以上のことから本構成は, 同一光路干渉計が構成されてお り， $\mathbf{e}_{\mathrm{cw}}$ と $\mathbf{e}_{\mathrm{ccw}}$ に対するファラデー効果による位相差のみを, 干渉信号として検出できることが分かる.

\section{2 用いる (TbY) IG 結晶とセンサ特性の評価方法}

今回の検討に用いた試料の外観をFig. 2 に示す．挿入図 に示したように, (110)面下の成長域から切り出した試料で

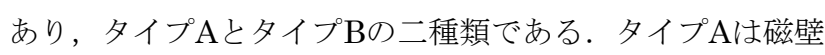
に対して平行な面で切り出したもので, [-110]方向に磁界 $H_{\mathrm{a}}$ を印加し，それと平行な方向に光を伝搬させ，プローブ に対して平行な磁界を測定するためのものである. タ

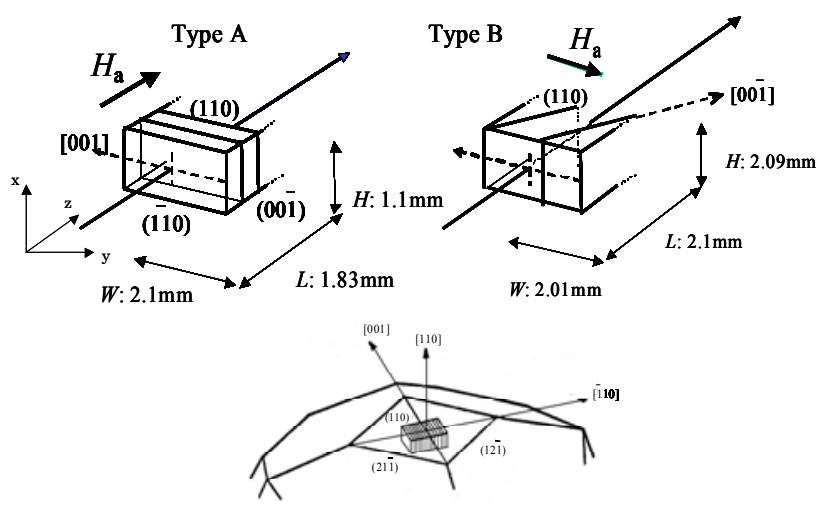

Fig. 2 Crystal cuts used for experiments. Inset shows crystal cut from (110) growth facset of (TbY)IG crystal grown by flux method. 
イプBは[110]方向から $45^{\circ}$ だけ傾けて切り出した試料に, [001]方向に対して $45^{\circ}$ の方向に磁界 $H_{a}$ を印加し, それと 垂直な方向に光を伝搬させるもので，プローブに対して垂 直な磁界を測定するために新たに提案するものである。こ れらのファラデー素子を評価するために, ファラデー効果 による磁化曲線の測定, 偏光顕微鏡による磁区観察を行っ た. また, 方位 $45^{\circ}$ の偏光子と検光子の間にファラデー素 子を配置したセンサ構成を用いて感度定数の測定を行った。 そして, Fig. 1 に示すような反射型のリング干渉計を光学 ベンチ上に構成して, センサ特性の評価を行った. 光源に は波長 $1.3 \mu \mathrm{m}$ のSLDを用い, ビート長の整数倍となるよ うに長さ $1 \mathrm{~m}$ のPMFを用いた. 受光器はInGaAsフォトダ イオードを用い，信号検出はロックインアンプを用いて行 った.

\section{3. 実験結果および考察}

\section{1 ファラデー素子の評価結果}

ファラデー効果の外部磁界依存性を測定して, 用いた素 子の磁化曲線を求めた. 結果を Fig. 3 および Fig.4 に示す. ○はゼロから飽和するまで正の磁界を， 口は正から負の磁 界を， $\triangle は$ 負の磁界からゼロに至る磁界を印可した場合の ファラデー回転角をそれぞれ示している. 両者ともに，上 ステリシスのない直線的な磁化曲線が得られていることが 分かる. 縞状磁区構造のそれぞれの磁区内は一軸異方性を 有し一様に磁化した単磁区構造状態として考えられるので, 磁化曲線はそれぞれの磁区における磁化過程の和として得 られると考えた5). さらに, タイプAの試料のように, 磁化 容易軸に垂直に外部磁界を印加寸る場合, ヒステリシスの 無い磁化過程が得られることが期待される8 ${ }^{8}$. 計算によ

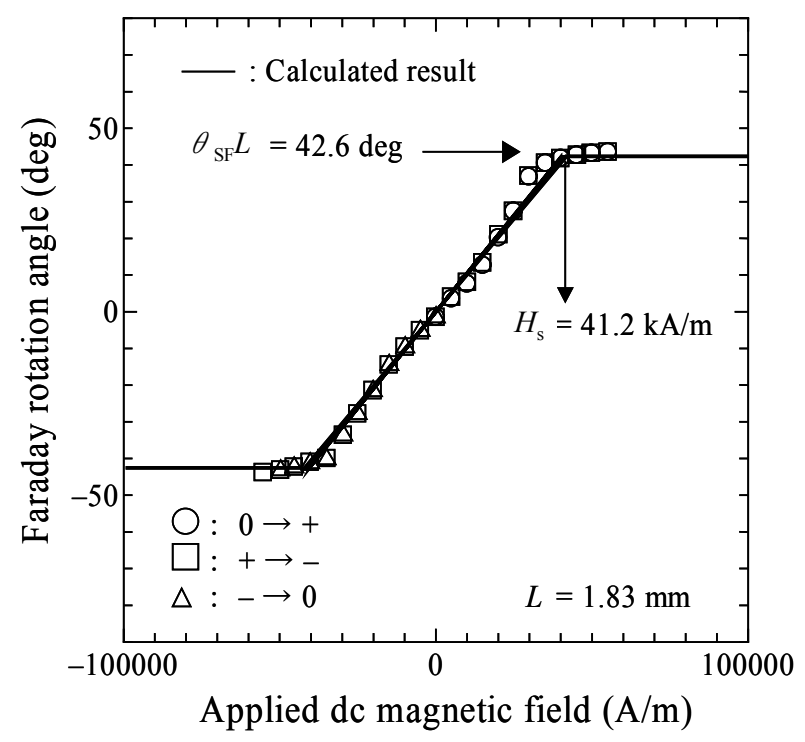

Fig. 3 Measurement results for Faraday rotation angle of Type-A sample as a function of applied magnetic field, $H_{\mathrm{a}}$.

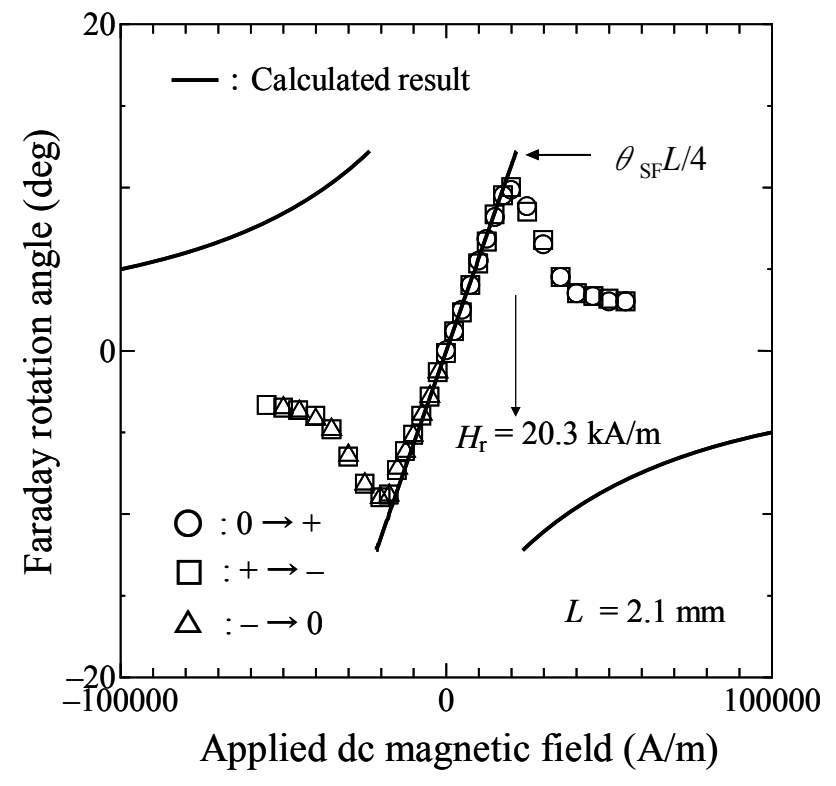

Fig. 4 Measurement results for Faraday rotation angle of Type-B sample as a function of applied magnetic field, $H_{\mathrm{a}}$.

る磁化曲線は, 単位体積当たりの磁気エネルギーと異方性 エネルギーの和が最小になるような条件から求め, さらに 反磁界の補正を行った. Fig.3 に実線で結果を示すが, 測 定結果と良い一致を示している。 そして, この試料の飽和 磁界 $\left(H_{\mathrm{s}}\right)$ は $41.2 \mathrm{kA} / \mathrm{m}$ であり, 飽和時のファラデー回転角 の值から, ファラデー回転能 $\left(\theta_{S F}\right)$ は $23.3 \% / \mathrm{mm}$ である ことが分かった. タイプBの試料の場合は, Fig. 5 に示すよ うに, 磁化容易軸に対して $45^{\circ}$ 及び $225^{\circ}$ の方向に外部磁 界が印加された二種類の磁区の磁化過程の和として考え
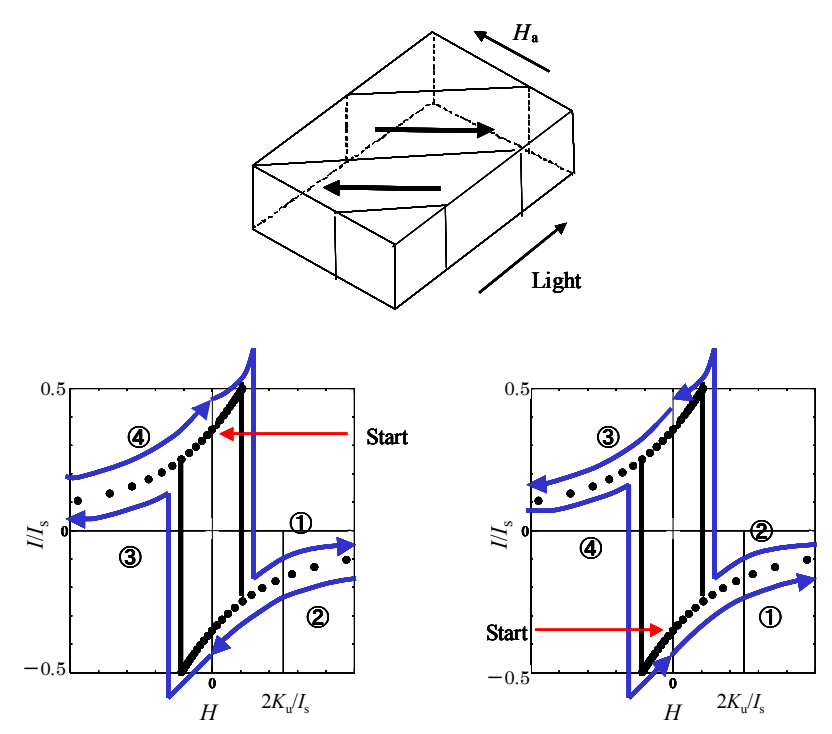

Fig. 5 Magnetization rotation process for Type-B sample. 

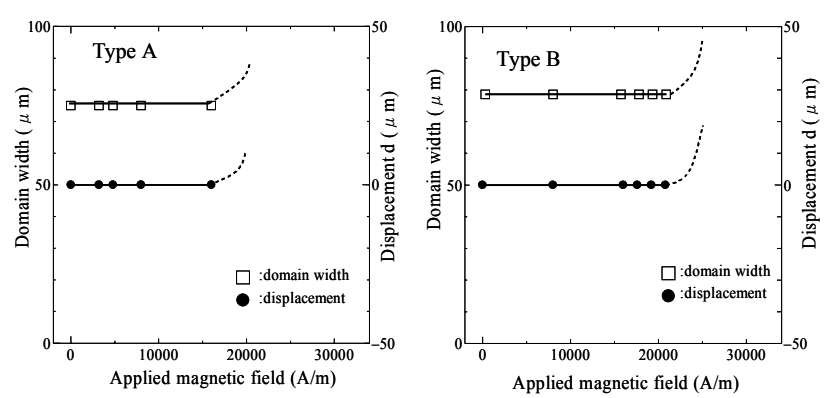

Fig. 6 Measurement results for domain width and displacement of domain wall as a function of applied dc magnetic field.

る. そして，ファラデー効果は，光の伝搬方向に平行な磁 化の成分に比例するので， $H_{\mathrm{a}}$ 方向に垂直な磁化成分を求め た。それぞれの磁区における磁化過程を計算した結果を Fig.5 に示しているが，それぞれは大きなヒステリシスを 示す. しかしながら, 二つの磁化過程を合成するとFig.4 に 実線で示したような結果となる. 印加磁界が小さい領域で はヒステリシスが補償され, 直線的な磁化過程が得られて いる．この線形性が良い磁界領域の最大值を $H_{\mathrm{r}}$ とする。 そ して, 計算結果から, 今回のような条件では $H_{\mathrm{r}}$ はタイプA における $H_{\mathrm{s}}$ の $1 / 2$ の值になり，合成した磁化の $H_{\mathrm{r}}$ での大き さは飽和磁化の $1 / 4$ になることから, ファラデー回転角も $\theta_{\mathrm{SF}} L$ の $1 / 4$ になることが分かった. $H_{\mathrm{r}}$ 以下での測定結果と 計算結果は良く一致しており，この試料の $H_{\mathrm{r}}$ は $20.3 \mathrm{kA} / \mathrm{m}$ であることが分かった。 そして，このような磁化過程のモ デルは，磁壁が移動しないことを仮定しているので，印加 磁界による磁壁移動の有無を偏光顕微鏡により確認した. 結果をFig.6に示す.タイプAの試料は磁区幅が約 $76 \mu \mathrm{m}$, タイプ $\mathrm{B} て ゙ は$ 約 $80 \mu \mathrm{m}$ の縞状磁区構造になっているが，タ

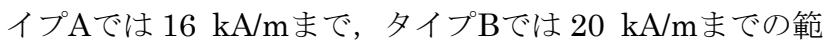
囲で，磁壁の移動と磁区幅の変化は見られなかった。しか し, それ以上の印可磁界領域では, 複雑な磁壁の移動が観 察された。特にタイプBの場合, Fig.4 に示すように， $H_{\mathrm{r}}$ 以 上の印加磁界の領域で, 計算結果では磁化の反転によって ファラデー効果の符号の反転が生じることを示しているが, 実験結果では符号の反転を示さずに連続的に飽和に至って

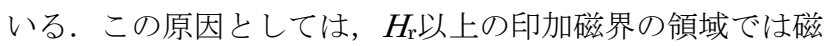
化は反転することなく, 磁化の回転に磁壁の移動が加わっ た磁化過程に変化していることが考えられるが，今後の検 討が必要である. 最後にファラデー素子の評価として, 感 度定数を測定した. 方位 $45^{\circ}$ の偏光子と検光子の間にファ ラデー素子を配置した透過型構成の場合, センサ出力は次 式で与えられる.

$$
I_{\mathrm{s}}=\frac{1}{2}\left|e_{0}\right|^{2}\left(1+\sin 2 \theta_{\mathrm{F}}\right)
$$

そして, 第二項の信号成分を第一項の DC 成分で除算して センサ信号としており, 感度定数 $(S)$ は単位印加磁界当た りのセンサ信号の大きさを百分率で示したものなので，そ

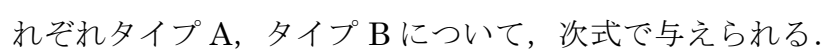

$$
\begin{gathered}
S_{\mathrm{A}}=\frac{\sin \left(2 \theta_{\mathrm{SF}} L H_{\mathrm{a}} / H_{\mathrm{s}}\right)}{H_{\mathrm{a}}} \times 100 \%, \\
S_{\mathrm{B}}=\frac{\sin \left(\theta_{\mathrm{SF}} L H_{\mathrm{a}} / 2 H_{\mathrm{r}}\right)}{H_{\mathrm{a}}} \times 100 \% .
\end{gathered}
$$

ここで， $H_{\mathrm{a}}$ は印可磁界強度である，長さが等しい場合，タ イプ $\mathrm{B}$ 感度定数は, タイプ $\mathrm{A} の ~ 1 / 2$ になることが分かる. 今回の場合について計算結果と測定結果を比較すると, 夕 イプ $\mathrm{A} の$ 計算值は $S_{\mathrm{A}, \mathrm{cal}}=3.6 \times 10^{-3} \% /(\mathrm{A} / \mathrm{m})$ であり，測定值

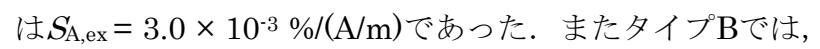
$S_{\mathrm{B}, \mathrm{cal}}=2.1 \times 10^{-3} \% /(\mathrm{A} / \mathrm{m}), \quad S_{\mathrm{B}, \mathrm{ex}}=2.0 \times 10^{-3} \% /(\mathrm{A} / \mathrm{m})$ であ った。両者は比較的良く一致しており，タイプ $\mathrm{B}$ の場合に 感度が低くなることが実験的にも分かった。

\section{2 光源と受光回路系に発生する雑音}

光源として LD を用いた場合，反射戻り光による雑音が 信号対雑音比(Signal-to-Noise Ratio：SNR)の劣化の原因 となることが考えられる。したがって，受光器に発生する 雑音を, LD および SLD を用いた場合について比較する測 定を行った。結果を Fig.7 に示す. 口およびロはそれぞれ 2 個の LD，○および○はそれぞれ二個の SLD に対する測 定結果を示す. LD と SLD の両者に二桁程度の差が生じて いることがわかる．また，受光回路系に発生する雑音はシ ヨット雑音と熱雑音の和と考え，次式で計算した結果も実 線で示してある.

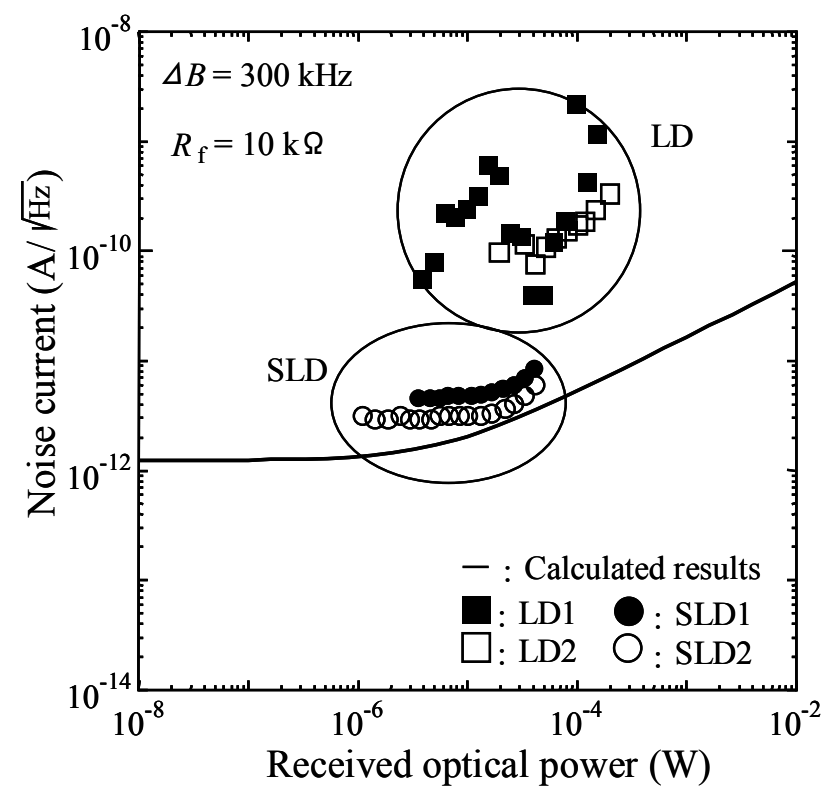

Fig. 7 Dependence of noise current at the photodetector on received optical power. 


$$
i_{\mathrm{n}}{ }^{2}=\left(2 q \eta \bar{P}+\frac{4 k T}{R_{\mathrm{sh}}}+\frac{4 k T}{R_{\mathrm{f}}}\right) \Delta B .
$$

ここで, $q$ は電荷素量, $\eta$ はフォトダイオードの変換効率, $\bar{P}$ は平均受光量, $\Delta B$ は帯域幅, $k$ はボルツマン係数, $T$ は 温度, $R_{\mathrm{sh}}$ はフォトダイオードの内部抵抗， $R_{\mathrm{f}}$ 電流電圧変 換回路のフィードバック抵抗である.今回の測定条件は, $\eta=0.85 \mathrm{~A} / \mathrm{W}, R_{\mathrm{sh}}=100 \mathrm{M} \Omega, R_{\mathrm{f}}=10 \mathrm{k} \Omega, T=300 \mathrm{~K}$, $\Delta B=300 \mathrm{kHz}$ である. SLDを用いた場合は計算值に近い值 を示しており，光源にSLDを用いることで, LD使用時に比 較して，雑音を大幅に低減できることが分かった.

\section{3 センサ特性評価}

得られたファラデ一素子を反射型リング干渉計に適応して, センサ特性の評価を行った. タイプA及びタイプBについて, 以下に述べるような項目について，同様な測定結果と考察 の内容が得られたので, ここでは今回新規に提案したタイ プBの試料を用いた場合で代表して説明する. Fig.8 に交流 磁界の測定結果を示す。磁界強度が $1 \mathrm{~A} / \mathrm{m}$ から $10^{4} \mathrm{~A} / \mathrm{m}$ の 範囲で良好な直線性が得られていることがわかる。 センサ 出力は式(7)で示されるが, 交流磁界測定時は, 系の変動の 影響を除去するために, 第二項の $\mathrm{AC}$ 成分を第一項のDC成 分で除算してセンサ出力としている. その計算結果を実線 で示してある，そして，センサの感度定数（S）は，反射型 構成なので透過型に対して感度が 2 倍となり，今回の場合 は次式で与えられる。

$$
S=\frac{\sin \left(\theta_{\mathrm{SF}} L H_{\mathrm{a}} / H_{\mathrm{r}}\right)}{H_{\mathrm{a}}} \times 100 \%
$$

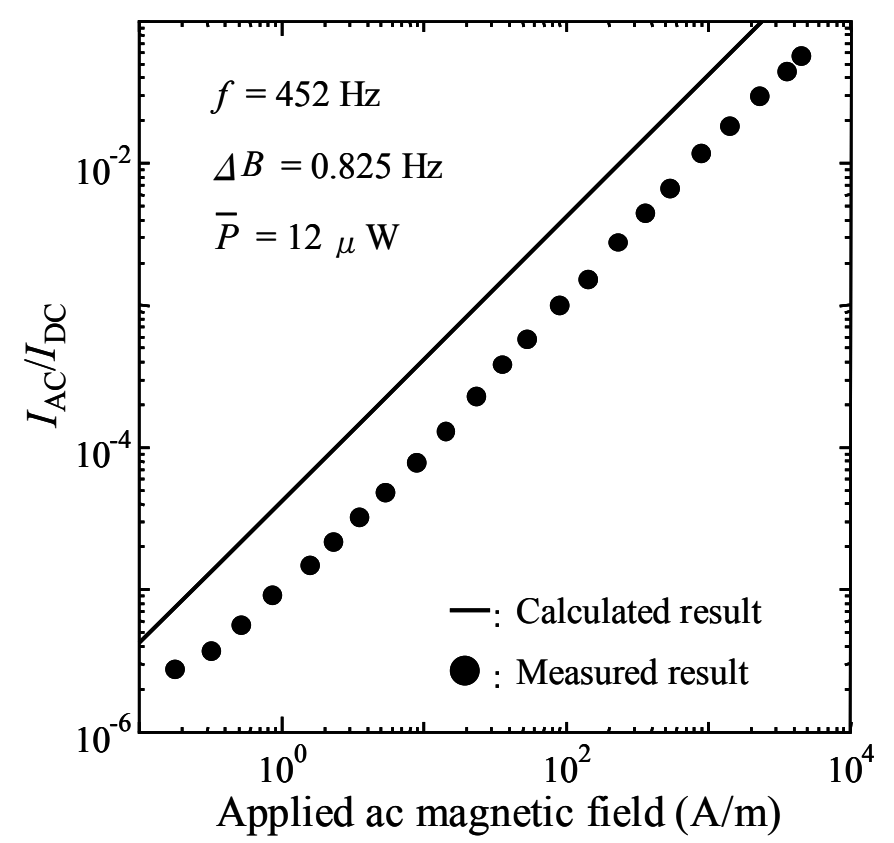

Fig. 8 Measured and calculated results of sensor output for applied ac magnetic field.

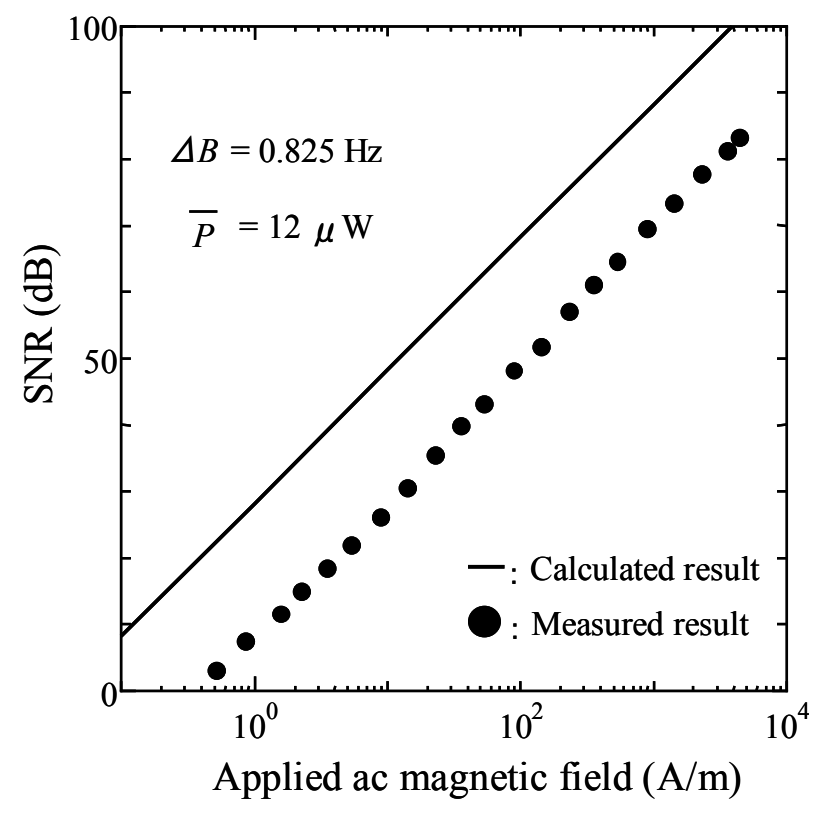

Fig. 9 Measured and calculated results of SNR for applied ac magnetic field.

感度定数の計算值として $S_{\mathrm{cal}}=4.2 \times 10^{-3} \% /(\mathrm{A} / \mathrm{m})$ が得られ るが，測定值は $S_{\mathrm{ex}}=1.08 \times 10^{-3} \% /(\mathrm{A} / \mathrm{m})$ であり，Fig.8 か らもわかるように計算值に対して $26 \%$ に低下しているこ とがわかった。また，SNRの測定結果をFig.9 に示す。ま た, Fig.7 で示されたように, 杂隹音は熱雑音とショット雑 音のみであると仮定してSNRの計算を行ったが，その結果 も併せて実線で示してある.雑音に等価な磁界強度 $4 \times 10^{-1}$ $\mathrm{A} / \mathrm{m}$ が達成されている。しかし，計算值に対して測定值は $-20 \mathrm{~dB}$ 程低い值を示し, センサ感度の低下がその主な原因 と考えられる.

\section{4 感度低下の原因}

センサ特性評価の結果，感度が $26 \%$ に低下していたが， その原因として以下の三点を検討した．光源として用いた SLD の発光スペクトル幅は LDに比較して広いので, 最初 に(TbY)IG 結晶のファラデー効果が持つ波長分散の影響を 計算により検討した。一般にファラデー回転能の波長依存 性は,

$$
\theta_{\mathrm{SF}}(\lambda) \propto \frac{1}{\lambda^{2}},
$$

で表される．センサ信号に光源の波長分布を考慮した場合 の干渉信号 $I_{\mathrm{f}}$ は9 ${ }^{9}$,

$$
I_{\mathrm{f}}=\int_{-\infty}^{\infty} \sin 4 \theta_{\mathrm{SF}}(\lambda) L \frac{H_{\mathrm{a}}}{H_{\mathrm{r}}} g(\lambda) d \lambda
$$

で表される. $g(\lambda)$ はLD $の$ 発光スペクトラムを示すガウス 分布である. 今回の場合, スペクトル分散は $\sigma=16.6 \mathrm{~nm}$, 
中心波長は $\lambda_{0}=1.32 \mu \mathrm{m}$ である. 計算結果は, LDを使用す る場合に相当するが, 単一波長での計算結果と同じであり， ファラデー効果の波長分散の影響は無視できることがわか った. 二点目の原因として, 受光器面上での $\mathbf{e}_{\mathrm{cw}}$ と $\mathbf{e}_{\mathrm{ccw}}$ のビ 一ム径の差が生じると, 干渉する成分が減少し, 感度に寄 与しないDC成分が増加することが考えられた.コリメータ から受光器までの光路長に右廻りと左廻りで差が生じてい たためであり, 測定の結果, 感度低下 $56 \%$ が推測された. 三点目に, 無反射(Anti-Reflection: AR)コートを施していな い光学部品からの反射光について検討した. 光源のコヒー レンス長が短いので, この反射光はDCレベルを増加させ, 感度低下の原因となる．測定の結果，定偏波ファイバ端お よびARコートを施していないファラデー素子からの反射 光が原因で感度が $48 \%$ に低下することがわかった. 最終的 には, 両者による感度の低下率が $27 \%$ と見積もられ, 実験 結果の $26 \%$ ほほぼ説明された. したがって, コリメータの 改善とARコートをすることで改善可能であることがわか った.

\section{4. まとめ}

本研究では, プローブ型光磁界センサの実現のために, 反射型リング干渉計を採用し，以下の検討結果を得た.

（1）プローブに対して平行および垂直な磁界を測定す るために, 縞状磁区構造を有する(TbY)IG 結晶を用 いた二種類のファラデー素子を提案した。 それぞれ の素子の磁化過程を評価した結果, 直線性の良い磁 化曲線とファラデー効果が得られた.
（2） SLD を光源に用いることで, 受光器に発生する雑音 の大幅な改善が成された.

（3）リング干渉型光磁界センサの出力は，良好な直線性 を示したが, 感度が計算值に対して $26 \%$ に低下して いた．その原因を検討した結果，コリメータの改善 と AR コートで解決できることを示した.

\section{References}

1) K. Bohnert, P. Gabus, J. Nehring, H. Brandle, and M. G. Brunzel: J. Lightw. Technol., 25, 3602 (2007).

2) N. Itoh, H. Minemoto, D. Ishiko, and S. Ishizuka: J. Magn. Soc. Jpn., 21, 637 (1997) (in Japanese).

3) S. Wakana, T. Ohara, M. Abe, E. Yamazaki, M. Kishi, and M. Tsuchiya: IEEE. Trans. Microwave Theory Tech., 48, 2611 (2000).

4) O. Kamada, and H. Tamura: IEEE Trans. Magn., 35, 3628 (1999).

5) K. Okubo, T. Nakaya, O. Kamada, and K. Shiraishi: J. Magn. Soc. Jpn., 30, 402 (2006) (in Japanese).

6) O. Mikami: Jpn. J. Opt. 19, 143 (1990) (in Japanese).

7) A. Yariv: Appl. Opt. 26, 4538 (1987).

8) K. Ohta : Jikikogaku no Kiso 2 (in Japanese), p. 287 (Kyoritsu Shuppan, Tokyo, 1973).

9) P. A. Flournoy, R. W. McClure, and G. Wyntjes: Appl.Opt., 11, 1907 (1972).

2009年11月9日受理，2010年2月17日再受理，2010年4月22日採録 